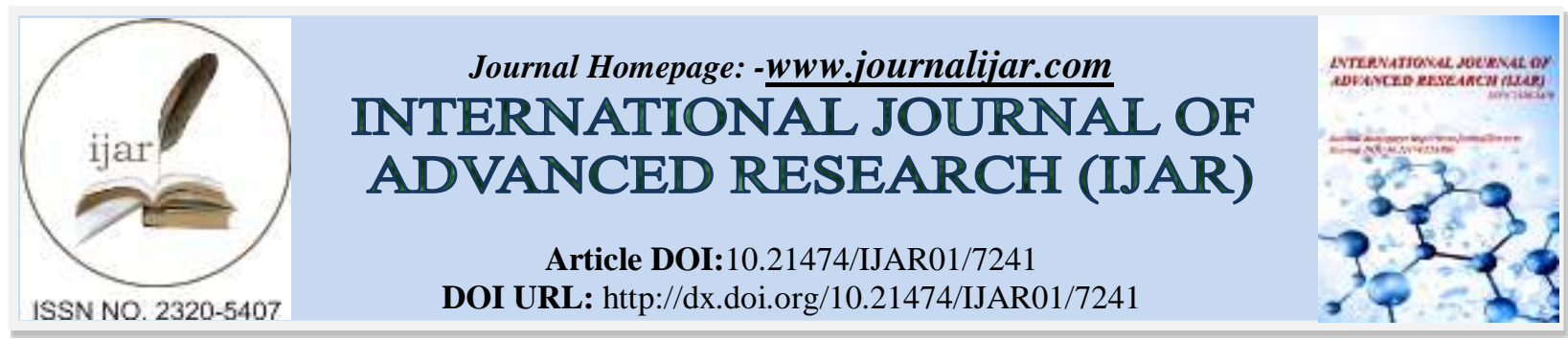

RESEARCH ARTICLE

\title{
HEAVY METAL POLLUTION IN GROUNDWATER OF KALI RIVER, SUB-BASIN, ALIGARH CITY, U.P. (INDIA).
}

Aqsa Irfan and S. Khurshid.

Department of Geology, Aligarh Muslim University, Aligarh, India.

\section{Manuscript Info}

Manuscript History

Received: 09 April 2018

Final Accepted: 11 May 2018

Published: June 2018

Keywords:-

Groundwater, Water quality,

Contamination, Aligarh, India.

\section{Abstract}

The study has been carried out to assess the groundwater quality of Kali river Sub-basin of Aligarh City U.P. India. About 100 water samples were collected during pre monsoon and post monsoon period for the year 2015 and analyzed for Heavy metals $(\mathrm{Cu}, \mathrm{Cd}, \mathrm{Cr}, \mathrm{Fe}, \mathrm{Mn}$, $\mathrm{Ni}, \mathrm{Pb}$,) to understand their behavior in subtropical fluvial system. The study have shown that there is a considerable variation in the concentration of heavy metal from one sampling station to other which may be due to the variation in the quality of industrial and sewage waste being added to the river at different places.

The result are compared with the specification prescribed by the Bureau of Indian standard (BIS) 1993 and World Health organization (WHO) 2004. It is revealed that the concentration of $\mathrm{Cr}, \mathrm{Cd}, \mathrm{Ni}, \mathrm{Pb}, \mathrm{Fe}$ and $\mathrm{Mn}$ is higher than the permissible limit prescribed by the Bureau of Indian standard (BIS) 1993 and World Health organization (WHO) 2004. The Heavy industrialization and the increasing urbanization are responsible for the rapidly increasing stress on the ground water of the area. The enormous quantity of waste water generated from domestic, commercial, industrial and other source has led to the problem of ground water in and around Aligarh City, and as in surface water of Kali River. It gives a sign of water quality deterioration, so it is necessary to take rational steps to manage water quality in this region before it becomes a crisis, as this will affect the economy and will also lead to various water-borne diseases.

Copy Right, IJAR, 2018,. All rights reserved.

\section{Introduction:-}

Ground water is used for Domestic, Industrial, water supply and irrigation all over the world. In the last few decades, there has been a tremendous increase in the demand for fresh water due to rapid growth of population and the accelerated pace of industrialization. Water quality is considered the main factor controlling health and the state of diseases in both men and animals (Faizanul Mukhtar, M. Yusuf Ansari 2014).

In the recent time Sand and gravel pits are filled up with domestic waste. This kind of disposal is not sealed and water soluble substances are dissolved by rainfall and infiltrate to the ground water, where by the quality of ground water, needed for drinking and industrial purposes is endangered. Heavy metals are among the most persistent of pollutants in the Ecosystem because of their resistance to decomposition in natural conditions (Khan T.A 2011). 
Untreated industrial effluents, especially the waste water from electroplating, chemical, electrical and electronics, textiles, metal based and other heavy engineering industries release high amount of undesirable metals as pollutants in to the water stream. These metals become partitioned among water, sediment and the Biota of the aquatic system. These elements as compared to most pollutants are not biodegradable and undergoes a biodegradable cycle in which the main path way is the natural water therefore it is very important now a days to see the concentration level of the heavy metals, pesticides and further chemical in water by the environmental research today (CPCB, 2008).

Suspended and Benthic sediments are also capable of removing the heavy metals from the aqueous phase. Heavy metals are non-Biodegradable and they may to toxic to the fauna and flora of the aquatic system. The absorption of heavy metals by sediments depends on the sediment characteristic, the type of heavy metal and other environmental condition (Nriagu, $1980 \mathrm{a}, \mathrm{b})$.

The problem of ground water quality are much more acute in the areas which are densely populated, thickly industrialized and have shallow ground water table (Patil V.T., Patil P.R. 2010).

Increasing water pollution causes not only the deterioration of water quality but also threatens human health and the balance of aquatic ecosystem, economic development and social prosperity. The water used for drinking purpose should be free from any toxic elements, living and non-living organism and excessive amount of minerals that may be hazardous to health. Some metals are naturally found in the body and are essential to human health (Harte et.al 1991).

In the recent past, Aligarh city has witnessed phenomenal growth, which has taken heavy toll of the ground water resource in the city. The water requirement of the city is fully met by the supplies from the ground water resources. Due to increasing trend of industrial and anthropogenic activities, all segments of environment are being polluted by various ways. It is therefore essential to analyze and assess the status of pollution and water quality in Aligarh city.

\section{Study Area:-}

The study area lie between lattitude $27^{\circ} 80^{\prime} \mathrm{N}$ and longitude $78^{\circ} 08^{\prime} \mathrm{E}$ longitude cover an area of about $4023 \mathrm{sq} . \mathrm{km}$. District Aligarh falling in central Ganga plain lie in the interfluvial tract of river Ganga and Yamuna. Aligarh district is a plain sloping gently from North-South located in a shallow fluvial depression between the two major river the Ganga and Yamuna. The area falls under tropical monsoon type of climate, maximum rainfall occurs during monsoon period June-September annual rainfall is $708.7 \mathrm{~mm}$. Average minimum temperature remain around $42^{\circ} \mathrm{C}$ and during summer and winter season temperature rest around $21^{\circ} \mathrm{C}$ and $10^{\circ} \mathrm{C}$. Raining season commerce in June and continue till September.

\section{Geology and Hydrogeology:-}

The entire Aligarh district falling in central Ganga plain lies in the interfluvial tract of Ganga and Yamuna. Hydrogeological data indicate that the area is underlain by moderately thick pile of quaternary sediment, which comprises of Sand of various grades clay and kankar.

Alluvial sediments overlies vindhyan group of rocks in an unconformable way. The thickness of deposit various from 287 to 380 metre. The stratigraphic sequence is as follow.

\begin{tabular}{|l|l|l|l|}
\hline Group & Age & Formation & Lithology \\
\hline & $\begin{array}{l}\text { Recent to upper } \\
\text { Pleistocene } \\
\text { Upper Pleistocene }\end{array}$ & $\begin{array}{l}\text { New Alluvium } \\
\text { Older } \\
\text { unconformity } \\
\text { Upper vindhyan }\end{array}$ & $\begin{array}{l}\text { Five Sand silt, clay with Gravel. } \\
\text { Paleozoic }\end{array}$ \\
Cambrian & $\begin{array}{l}\text { Clay with kankar of Sand of various } \\
\text { grades } \\
\text { Red stones and shales. }\end{array}$ \\
\hline
\end{tabular}

Older alluvium occupies the upland of the district while, the newer alluviums occupies lowland area along the courses of Ganga and Yamuna of their tributaries and paleochannel of Ganga and Kali River.

Hydrogeological setup of the study area:-In the study area three aquifer system is founded.

First Aquifer Group:-Most potential aquifer group generally occur between the depth range of 0-122 metres below ground level and covering almost entire area below soil capping. 
Second Aquifer Group:-This aquifer group is separated with the overlying shallow aquifer group by thick clay and it occur at the depth of 100 to 150 metres below ground level. The ground water is brackish to saline in nature in this aquifer group.

Third Aquifer Group:-The disposition of this aquifer group ranges between 130 to $300 \mathrm{mbgl}$. This aquifer group is mostly in confined state. It has the great quantitative potential but the quantity of formation water is brackish to saline cumulative thickness of granular zone in this aquifer group varies from 50-100 metre (Kumar, A, 2009).

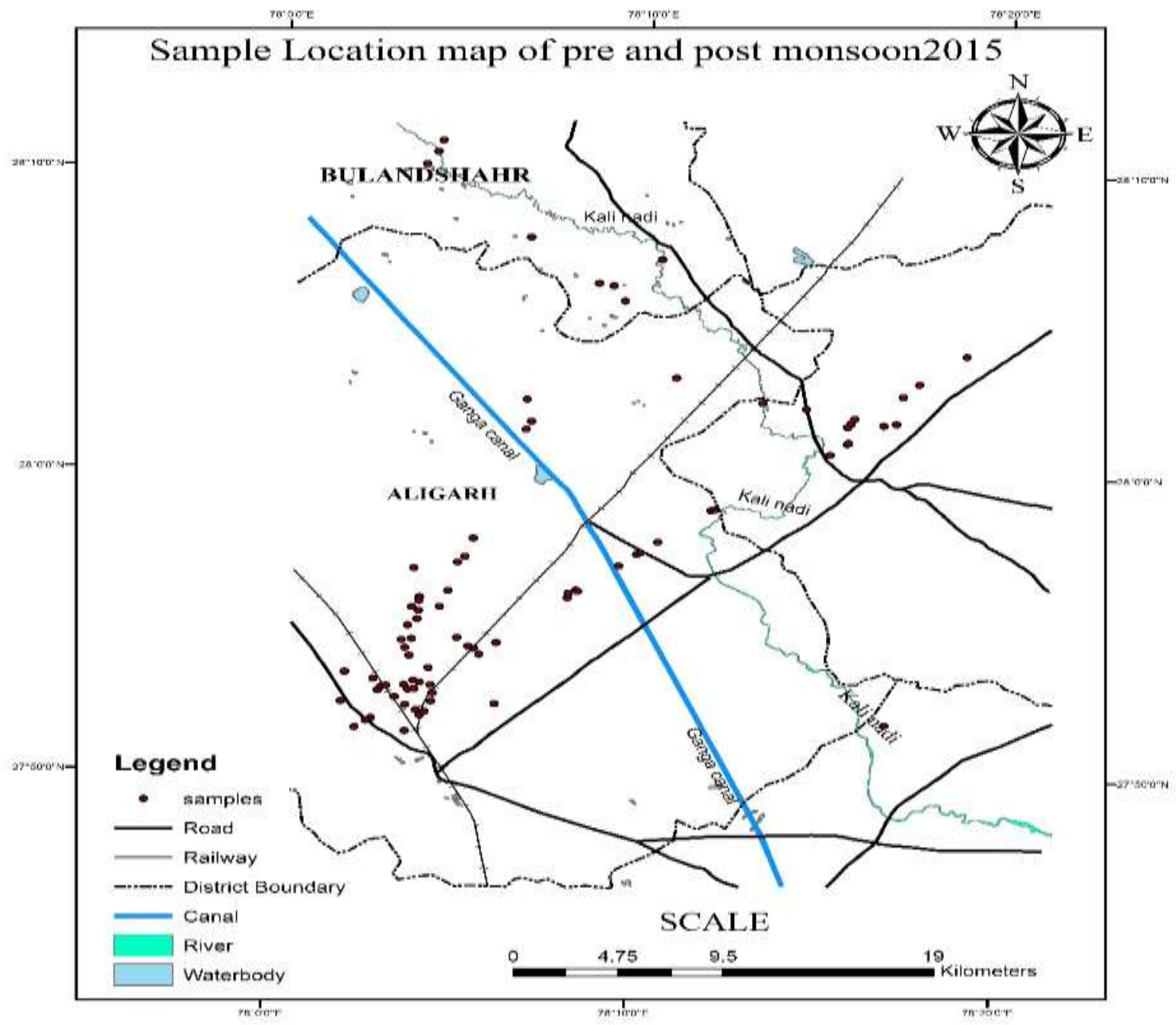

Fig 1:-Sample Location Map of the study area.

\section{Material and Methods:-}

In order to achieve the objectives of the present study hundred water samples were collected during pre-monsoon in the month of May and post monsoon seasons in the month of November during the year 2015. The site of sampling is selected randomly by considering the population, location and source.

Water samples has been collected from the handpumps in one litre plastic bottle and duly treated with Nitric acid. All the sampling, their preservation and procedure carried out for the examination of water and waste water recommended by APHA (2005) 


\section{Result and Discussion:-}

The results obtained were evaluated in accordance with the standards prescribed under Indian standard drinking water specification is: $10500: 1991$ of Bureau of Indian standard and WHO (2004).

Table 1:-Heavy metal showing minimum, maximum and average is pre and post monsoon.

\begin{tabular}{|l|l|l|l|l|l|l|l|l|l|l|l|l|l|l|}
\hline & Cu & \multicolumn{4}{l|}{ Mn } & \multicolumn{3}{l|}{ Fe } & \multicolumn{2}{l|}{ Pb } & Ni & \multicolumn{2}{l|}{ Cr } & \multicolumn{2}{l|}{ Cd } \\
\hline & Pre & Post & Pre & Post & Pre & Post & Pre & Post & Pre & Post & Pre & Post & Pre & Post \\
\hline Min & 0.04 & 0.36 & 0.02 & 0.61 & 0.03 & 0.4 & 0.02 & 0.08 & 0.05 & 0.5 & 0.02 & 0.33 & 0.01 & 0.3 \\
\hline Max & 5.78 & 2.03 & 0.5 & 2.1 & 2.3 & 6.11 & 0.2 & 5.3 & 0.9 & 1.64 & 2.2 & 5.2 & 0.1 & 1.0 \\
\hline Average & 0.77 & 0.85 & 0.1 & 1.14 & 0.59 & 2.54 & 0.1 & 1.90 & 0.61 & 1.07 & 0.34 & 30.2 & 0.03 & 0.64 \\
\hline
\end{tabular}

Table 2:-Result of heavy metal exceeding permissible limit

\begin{tabular}{|c|c|c|c|c|c|}
\hline \multirow[t]{2}{*}{$\begin{array}{l}\text { S. } \\
\text { No. }\end{array}$} & \multirow[t]{2}{*}{ Parameters } & \multirow{2}{*}{$\begin{array}{l}\text { (maximum allowable) } \\
\text { permissible limit as } \\
\text { per WHO and BIS } \\
\text { IS : } 10500: 2012\end{array}$} & $\begin{array}{l}\text { No of samples } \\
\text { Exceeding the } \\
\text { permissible limit. }\end{array}$ & $\begin{array}{l}\text { No of samples } \\
\text { Exceeding the } \\
\text { permissible limit }\end{array}$ & \multirow{2}{*}{$\begin{array}{l}\% \text { of } \\
\text { samples } \\
\text { above } \\
\text { permissible } \\
\text { limit }\end{array}$} \\
\hline & & & Pre-monsoon 2015 & Post-monsoon 2015 & \\
\hline 1 & Copper $(\mathbf{C u})$ & $1.5 \mathrm{ppm}$ & 20 & 14 & $17 \%$ \\
\hline 2 & Chromium (Cr) & $0.05 \mathrm{ppm}$ & 99 & 100 & $99.5 \%$ \\
\hline 3 & Cadmium $(\mathbf{C d})$ & $0.01 \mathrm{ppm}$ & 77 & 100 & $88.5 \%$ \\
\hline 4 & Iron $(\mathrm{Fe})$ & $1.0 \mathrm{ppm}$ & 17 & 78 & $47.5 \%$ \\
\hline 5 & Manganese (Mn) & $0.3 \mathrm{ppm}$ & 18 & 100 & $59 \%$ \\
\hline 6 & Nickel (Ni) & $0.3 \mathrm{ppm}$ & 94 & 100 & $97 \%$ \\
\hline 7 & Lead $(\mathbf{P b})$ & $0.01 \mathrm{ppm}$ & 80 & 99 & $89.5 \%$ \\
\hline
\end{tabular}

Numerous Anthropogenic activities including, industrial, municipal, commercial and agricultural manure, release a variety of potentially toxic heavy metal pollutants into the environment on daily basis (Nriagu, 1979, Nriagu and paeyna 1988). The multiplicity of the industrial processs give rise to a continuously changing pattern of distribution for each element in the biosphere creating in turn their own characteristic ecological consequence. The concentration of trace elements increase in water due to addition of industrial waste and sewage etc.

Chromium:- Chromium is one of the most widely distributed heavy metal in the earth crust. It is usually found in two oxidation state $\mathrm{Cr}^{+3}$ and $\mathrm{Cr}^{+6}$. $\mathrm{Cr}^{+3}$ get easily oxidized to $\mathrm{Cr}^{+6}$ which is more toxic. Chromium has also been reported as carcinogen (Tariq Salam Ansari, 2008).

The chromium concentration varied from 0.02-5.2 mg/l. 99.5\% of water samples are reported to have chromium concentration above the standard limit $(0.05 \mathrm{mg} / \mathrm{l})$ in the drinking water as prescribed by BIS. Pollution caused by Chromium is of great concern as it is toxic even at very low concentration. Normally, higher chromium values may be expected in terrains characterized by the presence of basic rocks. The study area, confined to Gangetic plains, the only suggestion that may be offered was Aligarh city chromium in ground water of the study area is of anthropogenic origin. High doses of chromium causes liver and kidney damage and chromate dust is carcinogenic (SE4H 2001, Mugica et. 2002).

Nickel:- The level of nickel usually found in food and water is not considered a serious health hazard. Nickel is a dietary requirement for many organism, but may be toxic in larger doses. Metallic nickel and some other nickel compounds are tetratogenic and carcinogenic. The Nickel concentration varies from $0.05-1.64 \mathrm{mg} / \mathrm{l}$. 97\% of the samples are found above the standard limit $(0.3 \mathrm{mg} / \mathrm{l})$ prescribed by BIS. The primary source of Nickel in drinking water is leaching from metals in contact with drinking water such as pipes and fitting (WHO 2005). Nickel is used mainly in the production of stainless, non-ferrous alloys and electroplating industries in Aligarh

Lead:-Lead is naturally derived from Galena (lead sulfide occurs as oxide and replaces the potassium in potassium feldspar) (SDWC 1977). Main sources of lead pollution are the effluent of industries such as paints, storage Batteries, printing and dyeing, fertilizer and insecticides. The lead concentration varies from $0.08-5.93 \mathrm{mg} / \mathrm{l}$. About $89.5 \%$ of the samples are found above the standard limit $(0.01 \mathrm{mg} / \mathrm{l})$ as prescribed by BIS. Lead can cause neurological and behavioural disorder, (Barzilay et al 1999). 
Cadmium:-Cadmium is one of the rarer elements in nature and occurs as its sulphide (Cds) and in association with sulphate ore. The Major Source of cadmium in the study area are effluents of industries connected with electroplating copper and nickel alloys, paints, nickel-cadmium batteries etc . The Cadmium concentration of water samples of the study area were varied from $0.01-1.0 \mathrm{mg} / \mathrm{l}$. About $88.5 \%$ of samples are found above the standard limit $(0.05 \mathrm{mg} / \mathrm{l})$.

Manganese:-Manganese compounds exist naturally in the environment as solid in the soil and small particles in the water. Manganese particles in air are present in dust particles. Manganese is one of the most abundant metal in the earth crust and usually occur together with Iron. The most abundant compounds of manganese are sulphide, oxide, carbonate and silicate. The Manganese concentration of water samples of the study area varies from 0.02-2.1 mg/l. About 59\% of the water samples are having manganese concentration above the standard limit $(0.3 \mathrm{mg} / \mathrm{l})$ as prescribed by BIS.Human enhance manganese concentrations in the air by industrial activities and through burning fossil fuel manganese that derives from human source can also enter surface water, ground water and sewage water.

Iron:-Iron is the most abundant element in earth crust but its deficiency occurs throughout the world. Anemia caused by lack of Iron is the commonest nutritional deficiency in the world (Raju, N.J 2006). The Iron concentration of water samples of the study area varied from $0.03-6.11 \mathrm{mg} / \mathrm{l}$. About $47 \%$ of the water samples are found above the standard limit $(1.0 \mathrm{mg} / \mathrm{l})$ as prescribed by BIS. High concentration of Iron generally cause bitter and astringent taste. The high value may be due to rusting of casing pipes, non-usage of bore wells for long periods and disposal of scrap iron in open areas due to industrial activity.

Copper:-Copper is an essential element for the functioning of humans, animal and plant. It is found in several enzymes and it is present as trace concentration in ground water. Copper is sometimes caused by contamination from mining operations, acid waters and corrosion in copper plumbing. The copper concentration of water samples of the study area were varied from $0.04-5.78 \mathrm{mg} / \mathrm{l} .17 \%$ of the water samples are found above the standard limit ( 1.5 $\mathrm{mg} / \mathrm{l}$ ) as prescribed by BIS. Copper poisoning systems include jaundice and anemia high level of copper may cause staining and bad tastes in addition to producing a corrrosive effect.

\section{Conclusion:-}

The Present study reveals that the concentration of trace elements such as $\mathrm{Cu}, \mathrm{Fe}, \mathrm{Pb}, \mathrm{Mn}, \mathrm{Cd}, \mathrm{Cr}, \mathrm{Ni}$ in the drinking water of the study area is above the maximum permissible limit as prescribed by BIS (2012).The level of heavy metals in ground water for Iron is (47.5\%), chromium (99.5\%) cadmium(88.5\%), Manganese(59\%), Nickel (97\%), lead $(89.5 \%)$ and copper (17\%) over all in the study area. Ground water samples are heavily contaminated by Iron, chromium, cadmium, lead, Nickel and Manganese. Chromium, Nickel, lead, Cadmium are found in water samples throughout the area. As for as the source of these elements is concern, the simplest assumption would be that Nickel, chromium, cadmium, and lead may be found in ground water from industries such as electroplating and industrial pollution. Reverse osmosis is considered best overall method for $\mathrm{Ni}, \mathrm{Pb}, \mathrm{Cd}, \mathrm{Cr}$ concentration reduction. Therefore, a proper planning and management is mandatory to alleviate the problem of intake water contamination in the study area. Table 3 (a) and 3 (b) are the results of heavy metal analysis of ground water samples pre monsoon 2015 and post monsoon 2015 water samples.

\section{Acknowledgment:-}

Author are thankful to prof. Syed Ahmad Ali Chairman, Department of Geology, AMU, Aligarh for providing necessary facilities.

Table 3(a):-Hydrochemical data of Trace elements pre-monsoon 2015 ground and surface water samples (mg/l)

\begin{tabular}{|l|l|l|l|l|l|l|l|l|l|}
\hline $\begin{array}{l}\text { SI.N } \\
\mathbf{0}\end{array}$ & Location & $\mathbf{C u}$ & $\mathbf{Z n}$ & $\mathbf{M n}$ & $\mathbf{F e}$ & $\mathbf{P b}$ & $\mathbf{N i}$ & $\mathbf{C r}$ & $\mathbf{C d}$ \\
\hline 1 & Quarsi Ramghat road HP1 & 0.051 & 0.53 & 0.091 & $\begin{array}{l}0.45 \\
9\end{array}$ & 0.328 & 0.6 & 0.35 & 0.1 \\
\hline 2 & $\begin{array}{l}\text { Talanagri , Hardware industry } \\
\text { HP1 }\end{array}$ & 0.058 & 0.14 & 0.052 & 0.2 & 0.122 & 0.4 & 0.34 & 0.03 \\
\hline 3 & Industrial Talanagri TW & 0.057 & 0.08 & 0 & 0.2 & 0.039 & 0.5 & 0.33 & 0.04 \\
\hline 4 & Talanagri ,Plastic industry (TW) & 0.05 & 0.16 & 0 & 0.3 & 0.127 & 0.4 & 0.31 & 0.04 \\
\hline
\end{tabular}




\begin{tabular}{|c|c|c|c|c|c|c|c|c|c|}
\hline 5 & Talanagri, Main road HP(P) & 0.05 & 0.3 & 0.105 & 0.2 & 0.028 & 0.5 & 0.36 & 0.02 \\
\hline 6 & Harduaganj HP(P) & 0.052 & 0.53 & 0.097 & 0.2 & 0.152 & 0.6 & 0.37 & 0.01 \\
\hline 7 & Barotha bridge HP(I) & 0.062 & 0.01 & 0 & 0.3 & 0.087 & 0.6 & 0.31 & 0.02 \\
\hline 8 & $\begin{array}{l}\text { Surface water body (Barotha } \\
\text { canal) }\end{array}$ & 0.051 & 0 & 0 & 0.1 & 0.114 & 0.6 & 0.34 & 0.03 \\
\hline 9 & Safad pura HP(P) & 0.055 & 0.05 & 0.002 & 0.5 & 0.102 & 0.6 & 0.35 & 0.05 \\
\hline 10 & Kali nadi & 0.058 & 0 & 0.115 & 1.02 & 0.152 & 0.6 & 0.4 & 0.07 \\
\hline 11 & kali nadi (Bear factory) & 0.45 & 0.005 & 0.254 & 1.3 & 0.101 & 0.6 & 0.6 & 0.09 \\
\hline 12 & Kali nadi (Down stream) & 0.08 & 0 & 0.121 & 1.2 & 0.081 & 0.6 & 0.5 & 0.07 \\
\hline 13 & Distillary HP(P) & 0.07 & 2.81 & 0.272 & 0.3 & 0.128 & 0.05 & 0.17 & 0.074 \\
\hline 14 & Daugarhi HP(I) & 0.06 & 0.077 & 0.028 & 0.1 & 0.146 & 0 & 0.3 & 0.058 \\
\hline 15 & (7 km before atrauli) HP(I) & 0.06 & 2.33 & 0.509 & 0.1 & 0.077 & 0.2 & 0.2 & 0.072 \\
\hline 16 & Chaumuwa village HP(I) & 0.07 & 0 & 0.03 & 0.3 & 0.107 & 0.2 & 0.2 & 0.075 \\
\hline 17 & Madholi HP(P) & 0.22 & 0 & 0.105 & 0.3 & 0.164 & 0.4 & 0.07 & 0.07 \\
\hline 18 & Atrauli HP(P) & 0.1 & 0.64 & 0.122 & 0.4 & 0.08 & 0.4 & 0.17 & 0.086 \\
\hline 19 & $\begin{array}{l}\text { Sham nursury and farm atrauli } \\
\text { HP(I) }\end{array}$ & 0.09 & 0.39 & 0.122 & 0.3 & 0.074 & 0.3 & 0.09 & 0.071 \\
\hline 20 & Pilkhuni HP(P) & 0.09 & 0.18 & 0 & 0.1 & 0.132 & 0.4 & 0.18 & 0.061 \\
\hline 21 & Jaiveer singh gate $\mathrm{HP}(\mathrm{P})$ & 0.08 & 0.12 & 0.028 & 0.3 & 0.111 & 0.4 & 0.2 & 0.075 \\
\hline 22 & $\begin{array}{l}\text { Mandir jaiveer singh } \mathrm{HP}(\mathrm{P}) \\
\text { Village }\end{array}$ & 0.09 & 1.16 & 0 & 0.2 & 0.148 & 0.5 & 0.1 & 0.073 \\
\hline 23 & $\begin{array}{llll}\text { Mandir } & \text { jaiveer } & \text { singh } & \text { HP(I) } \\
\text { Village }\end{array}$ & 0.08 & 0 & 0.11 & 0.2 & 0.084 & 0.4 & 0.1 & 0.069 \\
\hline 24 & Gardya chauk HP(P) & 0.1 & 0.15 & 0.104 & 0.1 & 0.137 & 0.4 & 0.09 & 0.066 \\
\hline 25 & $\begin{array}{l}\text { City Hazrat kale shah naya bazar } \\
\text { HP(I) }\end{array}$ & 0.08 & 0 & 0.016 & 0.1 & 0.133 & 0.5 & 0.08 & 0.066 \\
\hline 26 & $\begin{array}{l}\text { City Hazrat kale shah naya bazar } \\
\text { HP(I) }\end{array}$ & 0.09 & 0 & 0.266 & 0.1 & 0.125 & 0.6 & 0.08 & 0.077 \\
\hline 27 & Atrauli HP(I) & 0.09 & 0.05 & 0.078 & 0.2 & 0.109 & 0.6 & 0.082 & 0.069 \\
\hline 28 & Chattari HP(P) & 0.09 & 0.35 & 0.07 & 0.03 & 0.159 & 0.6 & 0.34 & 0.066 \\
\hline 29 & Gardya chauk HP(P) & 0.09 & 0.19 & 0.104 & 0.06 & 0.133 & 0.6 & 0.35 & 0.078 \\
\hline 30 & Janakpur (TW) & 0.1 & 0 & 0.284 & 0.5 & 0.123 & 0.7 & 0.33 & 0.078 \\
\hline 31 & $\begin{array}{l}\text { Kali nadi, (godha atrauli } \\
\text { margpur) }\end{array}$ & 4.3 & 0 & 0.136 & 1.07 & 0.072 & 0.6 & 0.33 & 0.064 \\
\hline 32 & Godha atrauli margpur HP(I) & 3.2 & 0.23 & 0.266 & 1.02 & 0.174 & 0.7 & 0.5 & 0.018 \\
\hline 33 & Memdhi (TW) & 0.2 & 0 & 0.074 & 0.4 & 0.061 & 0.6 & 0.14 & 0.029 \\
\hline 34 & Chattari HP(I) & 0.05 & 0.13 & 0.099 & 0.2 & 0.154 & 0.7 & 0.35 & 0.032 \\
\hline 35 & $\begin{array}{l}\text { Surface water body (Somna } \\
\text { canal) }\end{array}$ & 1.1 & 0 & 0.025 & 0.7 & 0.143 & 0.8 & 0.05 & 0.024 \\
\hline 36 & Java HP(P) & 2.1 & 0 & 0.028 & 0.3 & 0.151 & 0.7 & 0.36 & 0.031 \\
\hline 37 & Cherrat HP(P) & 1.04 & 0 & 0.083 & 0.3 & 0.119 & 0.7 & 0.41 & 0.011 \\
\hline 38 & $\begin{array}{llll}\text { Ayesha } & \text { Tarin } & \text { Public } & \text { school } \\
\text { HP(I) } & & & \\
\end{array}$ & 1.5 & 2.11 & 0.389 & 0.2 & 0.174 & 0.8 & 2.2 & 0.02 \\
\hline 39 & Jalalpur,Khair road HP(I) & 1.3 & 0 & 0.117 & 0.3 & 0.167 & 0.8 & 0.2 & 0.02 \\
\hline 40 & Khair road,Petrol Pump HP(I) & 2.2 & 0 & 0.024 & 0.4 & 0.166 & 0.9 & 0.1 & 0.02 \\
\hline 41 & Gonda road, Chauraha HP(I) & 0.8 & 0 & 0.16 & 0.2 & 0.172 & 0.9 & 0.02 & 0.03 \\
\hline 42 & Makhdoon nagar HP(I) & 0.9 & 0 & 0.082 & 0.4 & 0.125 & 0.8 & 0.32 & 0.02 \\
\hline 43 & Allana, slaughter house HP(I) & 1.2 & 0.83 & 0.104 & 0.5 & 0.194 & 0.8 & 0.18 & 0.04 \\
\hline 44 & $\begin{array}{l}\text { Slaughter house ,HMA Agro } \\
\text { HP(P) }\end{array}$ & 2.3 & 0 & 0 & 0.3 & 0.105 & 0.8 & 0.11 & 0.03 \\
\hline 45 & Mathura road petrol pump HP(I) & 0.7 & 0 & 0.14 & 0.4 & 0.08 & 0.8 & 0.36 & 0.03 \\
\hline 46 & Mathura road HP(I) & 2.5 & 0.11 & 0.054 & 0.7 & 0.096 & 0.8 & 0.45 & 0.01 \\
\hline 47 & Bhujpura chauraha HP(I) & 1.8 & 0 & 0.028 & 0.3 & 0.121 & 0.8 & 0.31 & 0.02 \\
\hline
\end{tabular}




\begin{tabular}{|c|c|c|c|c|c|c|c|c|c|}
\hline 48 & Kasim nagar HP(I) & 1.7 & 0.43 & 0.1 & 0.4 & 0.14 & 0.9 & 0.4 & 0.04 \\
\hline 49 & $\begin{array}{l}\text { Jungle garhi (Bore well } 150 \text { feet } \\
\text { deep) }\end{array}$ & 0.9 & 0 & 0.013 & 0.4 & 0.167 & 0.8 & 0.39 & 0.01 \\
\hline 50 & Jungle garhi (Supply water) & 0.8 & 0 & 0.059 & 0.2 & 0.147 & 0.9 & 0.46 & 0.03 \\
\hline 51 & Saria mia HP(I) & 1.4 & 0 & 0.091 & 0.7 & 0.143 & 0.8 & 0.45 & 0.003 \\
\hline 52 & Guriya bagh HP(I) & 2.1 & 1.23 & 0.205 & 0.4 & 0.152 & 0.9 & 0.49 & 0.027 \\
\hline 53 & Baradari chauraha (Bore well) & 1.8 & 0.24 & 0.143 & 0.5 & 0.152 & 0.9 & 0.43 & 0.02 \\
\hline 54 & $\begin{array}{l}\text { Baradari chauraha } \\
\text { sible) }\end{array}$ & 1.9 & 0 & 0.135 & 0.3 & 0.165 & 0.9 & 0.39 & 0.02 \\
\hline 55 & Kaila nagar HP(I) & 5.78 & 0 & 0.14 & 0.4 & 0.146 & 0.8 & 0.38 & 0.02 \\
\hline 56 & Kaila nagar HP(I) & 5.41 & 0.05 & 0.204 & 0.5 & 0.152 & 0.06 & 0.38 & 0.04 \\
\hline 57 & Medical road dodhpur HP(I) & 1.6 & 0 & 0.061 & 0.5 & 0.072 & 0.15 & 0.52 & 0.03 \\
\hline 58 & Jamalpur, near eidgah HP(I) & 1.2 & 0 & 0.336 & 1.4 & 0.174 & 0.5 & 0.42 & 0.02 \\
\hline 59 & Near Albarkat jamalpur HP(I) & 0.4 & 0.05 & 0.223 & 0.4 & 0.17 & 0.4 & 0.44 & 0.02 \\
\hline 60 & $\begin{array}{lll}\text { Dairy farm, Anoopshar road } \\
\text { HP(I) }\end{array}$ & 0.3 & 0 & 0.214 & 0.5 & 0.101 & 0.5 & 0.39 & 0.01 \\
\hline 61 & Cherrat,near Heinz HP(P) & 0.6 & 0.32 & 0.196 & 0.7 & 0.152 & 0.5 & 0.39 & 0.02 \\
\hline 62 & Java HP(P) & 0.3 & 0 & 0.047 & 0.6 & 0.155 & 0.6 & 0.4 & 0.02 \\
\hline 63 & Kali nadi(Chattari ) & 0.8 & 0 & 0.163 & 2.3 & 0.076 & 0.6 & 0.39 & 0.006 \\
\hline 64 & Kali nadi(Chattari) & 1.06 & 0 & 0.313 & 2.2 & 0.122 & 0.5 & 0.41 & 0 \\
\hline 65 & Kali nadi(Chattari) & 0.4 & 0 & 0.292 & 2.05 & 0.189 & 0.4 & 0.36 & 0 \\
\hline 66 & Chattari Bulandshar HP(I) & 0.9 & 0 & 0.345 & 0.6 & 0.129 & 0.7 & 0.35 & 0.01 \\
\hline 67 & Chattari Main Market HP(P) & 1.5 & 0 & 0.218 & 0.6 & 0.177 & 0.6 & 0.4 & 0 \\
\hline 68 & Kamona Gau HP(P) & 1.8 & 0 & 0.068 & 0.5 & 0.151 & 0.6 & 0.4 & 0.007 \\
\hline 69 & Pahasu HP(P) & 1.1 & 0 & 0.075 & 0.7 & 0.169 & 0.5 & 0.38 & 0 \\
\hline 70 & Kali nadi ,(shikarpur road phasu) & 0.4 & 0 & 0.262 & 1.1 & 0.117 & 0.6 & 0.31 & 0.017 \\
\hline 71 & Kali nadi ,(shikarpur road phasu) & 0.3 & 0 & 0.297 & 1.6 & 0.088 & 0.6 & 0.37 & 0.035 \\
\hline 72 & $8 \mathrm{~km}$ before shikarpur road TW & 0.5 & 0 & 0.381 & 0.6 & 0.161 & 0.5 & 0.37 & 0.026 \\
\hline 73 & Kali nadi( Bulandshar upstream) & 0.6 & 0 & 0.313 & 1.11 & 0.096 & 0.6 & 0.37 & 0.01 \\
\hline 74 & Kali nadi( Bulandshar upstream) & 1.3 & 0 & 0.368 & 0.9 & 0.195 & 0.6 & 0.38 & 0.01 \\
\hline 75 & Bulandshar HP(P) & 0.9 & 0 & 0.209 & 0.3 & 0.048 & 0.7 & 0.33 & 0.018 \\
\hline 76 & Sarsol HP(I) & 0.6 & 0 & 0.232 & 0.7 & 0.196 & 0.5 & 0.37 & 0.008 \\
\hline 77 & ITI Aligarh HP(I) & 1.5 & 0 & 0.052 & 0.3 & 0.202 & 0.6 & 0.37 & 0.01 \\
\hline 78 & Exhibition ground HP(I) & 2.8 & 0 & 0.165 & 0.3 & 0.109 & 0.7 & 0.33 & 0 \\
\hline 79 & Delhi gate, $\mathrm{HP}(\mathrm{I})$ & 1.3 & 0.43 & 0.594 & 1.2 & 0.106 & 0.7 & 0.41 & 0 \\
\hline 80 & Upper kote HP(I) & 1.6 & 0.52 & 0.393 & 0.4 & 0.179 & 0.8 & 0.43 & 0.014 \\
\hline 81 & $\begin{array}{l}\text { Madar gate, Achal road chauraha } \\
\text { HP(I) }\end{array}$ & 0.1 & 0 & 0.162 & 0.6 & 0.176 & 0.7 & 0.35 & 0.018 \\
\hline 82 & Saria sultan agra road $\mathrm{HP}(\mathrm{I})$ & 0.06 & 0.15 & 0.364 & 0.8 & 0.076 & 0.7 & 0.38 & 0.02 \\
\hline 83 & Khirni road,agra road HP(I) & 0.05 & 1.18 & 0.41 & 0.7 & 0.156 & 0.7 & 0.35 & 0 \\
\hline 84 & Sasni gate HP(I) & 0.04 & 0 & 0.222 & 0.7 & 0.12 & 0.7 & 0.34 & 0.01 \\
\hline 85 & Rasalganj HP(I) & 0.05 & 0.97 & 0.261 & 0.5 & 0.121 & 0.7 & 0.42 & 0.02 \\
\hline 86 & Dhanipur mandi Etah road HP(I) & 0.049 & 0 & 0.378 & 0.5 & 0.146 & 0.6 & 0.43 & 0.015 \\
\hline 87 & Firdaus nagar HP(I) & 0.058 & 0 & 0.245 & 0.6 & 0.21 & 0.6 & 0.43 & 0.009 \\
\hline 88 & Qila road HP(I) & 0.051 & 0.099 & 0.273 & 0.7 & 0.167 & 0.6 & 0.43 & 0.08 \\
\hline 89 & $\begin{array}{l}\text { Patwari ka nagla opp riding field } \\
\text { HP(I) }\end{array}$ & 0.053 & 0 & 0.509 & 0.4 & 0.142 & 0.7 & 0.38 & 0.01 \\
\hline 90 & $\begin{array}{l}\text { Patwari ka nagla street no } 1 \\
\text { HP(I) }\end{array}$ & 0.06 & 0 & 0.181 & 0.7 & 0.161 & 0.7 & 0.45 & 0.02 \\
\hline 91 & Shehanshabad HP(I) & 0.06 & 0 & 0.177 & 0.6 & 0.221 & 0.7 & 0.35 & 0.002 \\
\hline 92 & Riaz colony HP(P) & 0.8 & 0 & 0.209 & 0.7 & 0.175 & 0.8 & 0.35 & 0.008 \\
\hline 93 & Barola HP(I) & 0.07 & 0 & 0.154 & 0.4 & 0.157 & 0.8 & 0.33 & 0.002 \\
\hline 94 & Loco abadi HP(I) & 0.07 & 0 & 0.207 & 0.6 & 0.07 & 0.7 & 0.37 & 0 \\
\hline 95 & Govind nagar, near bhujpura & 0.4 & 1.28 & 0.317 & 2.4 & 0.163 & 0.7 & 0.32 & 0.001 \\
\hline
\end{tabular}




\begin{tabular}{|c|c|c|c|c|c|c|c|c|c|}
\hline & $\mathrm{HP}(\mathrm{I})$ & & & & & & & & \\
\hline 96 & $\begin{array}{l}\text { Shahjamal near karbala (Bore } \\
\text { well) }\end{array}$ & 0.06 & 0 & 0.21 & 0.5 & 0.164 & 0.7 & 0.34 & 0.009 \\
\hline 97 & Shahjamal near karbala HP(I) & 0.06 & 0 & 0.183 & 1.09 & 0.179 & 0.7 & 0.31 & 0.012 \\
\hline 98 & Shahjamal opp Eidgah gate HP(I) & 0.06 & 1.43 & 0.562 & 0.77 & 0.178 & 0.7 & 0.31 & 0.074 \\
\hline 99 & $\begin{array}{lll}\text { Kali nadi } & \text { (Cherra) } 1 \mathrm{~km} & \text { from } \\
\text { Pilakao } & & \\
\end{array}$ & 0.058 & 0 & 0.418 & 1.5 & 0.087 & 0.8 & 0.32 & 0.066 \\
\hline \multirow[t]{2}{*}{100} & $\begin{array}{lll}\text { Kali nadi } & \text { (Cherra) } 1 \mathrm{~km} & \text { from } \\
\text { Pilakao } & & \\
\end{array}$ & 0.068 & 0 & 0.322 & 2.3 & 0.125 & 0.8 & 0.33 & 0.082 \\
\hline & Average & $\begin{array}{l}0.7774 \\
1\end{array}$ & $2^{0.2}$ & 0.17 & 0.59 & $3^{0.1}$ & $1^{0.6}$ & $4 \quad 0.3$ & 0.03 \\
\hline
\end{tabular}

Table 3(b):-Hydrochemical data of Trace element post - monsoon 2015 ground and surface water samples (mg/l)

\begin{tabular}{|c|c|c|c|c|c|c|c|c|c|}
\hline $\begin{array}{l}\text { SI.N } \\
\text { o }\end{array}$ & Location & $\mathbf{C u}$ & $\mathbf{Z n}$ & Mn & $\mathbf{F e}$ & $\mathbf{P b}$ & $\mathbf{N i}$ & $\mathrm{Cr}$ & Cd \\
\hline 1 & Quarsi Ramghat road HP1 & 0.8 & 0.63 & 0.73 & 3.94 & 1.78 & 0.63 & 0.33 & 0.51 \\
\hline 2 & Talanagri, Hardware industry HP1 & 0.75 & 0.69 & 1 & 3.38 & 1.81 & 0.75 & 0.69 & 0.46 \\
\hline 3 & Industrial Talanagri TW & 0.7 & 0.75 & 0.68 & 2.42 & 1.91 & 0.78 & 0.93 & 0.45 \\
\hline 4 & Talanagri ,Plastic industry (TW) & 0.78 & 0.88 & 0.64 & 2.07 & 2.08 & 0.94 & 1.21 & 0.5 \\
\hline 5 & Talanagri, Main road HP(P) & 0.76 & 1.07 & 0.75 & 3.15 & 1.99 & 0.79 & 1.08 & 0.47 \\
\hline 6 & Harduaganj HP(P) & 0.74 & 1.47 & 0.63 & 2.5 & 2.12 & 0.78 & 1.02 & 0.56 \\
\hline 7 & Barotha bridge HP(I) & 0.75 & 1.21 & 0.71 & 1.9 & 2.28 & 0.96 & 1.11 & 0.51 \\
\hline 8 & Surface water body (Barotha canal) & 1.24 & 1.09 & 0.61 & 1.42 & 2.14 & 0.65 & 1.41 & 0.54 \\
\hline 9 & Safad pura HP(P) & 1.23 & 1.28 & 0.66 & 0.86 & 2.33 & 1.13 & 1.18 & 0.53 \\
\hline 10 & Kali nadi & 1.26 & 1.79 & 0.62 & 2.14 & 2.57 & 0.79 & 1.33 & 0.54 \\
\hline 11 & kali nadi (Bear factory) & 1.41 & 1.3 & 1.16 & 2.97 & 2.59 & 1.05 & 1.43 & 0.56 \\
\hline 12 & Kali nadi (Down stream) & 1.69 & 1.44 & 0.97 & 2.75 & 2.96 & 1.56 & 1.31 & 0.55 \\
\hline 13 & Distillary HP(P) & 1.51 & 1.2 & 1.08 & 4.51 & 2.98 & 1.4 & 1.68 & 0.59 \\
\hline 14 & Daugarhi HP(I) & 1.5 & 1.15 & 0.91 & 0.1 & 2.9 & 1.5 & 1.75 & 0.55 \\
\hline 15 & (7 km before atrauli) HP(I) & 1.68 & 1.12 & 0.81 & 0 & 3.35 & 1.27 & 1.95 & 0.61 \\
\hline 16 & Chaumuwa village HP(I) & 1.62 & 1.1 & 0.84 & 0.84 & 3.15 & 1.04 & 1.89 & 0.65 \\
\hline 17 & Madholi HP(P) & 1.51 & 1.19 & 0.91 & 2.82 & 3.31 & 1.38 & 1.96 & 0.68 \\
\hline 18 & Atrauli HP(P) & 1.57 & 1.31 & 0.85 & 1.22 & 3.21 & 1.13 & 1.75 & 0.69 \\
\hline 19 & $\begin{array}{l}\text { Sham nursury and farm atrauli } \\
\text { HP(I) }\end{array}$ & 1.85 & 1.72 & 0.88 & 0 & 1.07 & 1.51 & 1.65 & 0.67 \\
\hline 20 & Pilkhuni HP(P) & 1.57 & 1.51 & 0.85 & 1.51 & 1.07 & 1.29 & 1.66 & 0.74 \\
\hline 21 & Jaiveer singh gate HP(P) & 2.03 & 1.76 & 0.93 & 2.65 & 1.09 & 1.63 & 1.55 & 0.71 \\
\hline 22 & Mandir jaiveer singh HP(P) Village & 1.74 & 1.7 & 0.86 & 3.15 & 1.19 & 1.34 & 1.58 & 0.7 \\
\hline 23 & Mandir jaiveer singh HP(I) Village & 1.73 & 1.14 & 0.98 & 3.45 & 1.25 & 1.13 & 1.61 & 0.69 \\
\hline 24 & Gardya chauk HP(P) & 1.59 & 1.19 & 0.96 & 2.64 & 1.38 & 1.3 & 1.7 & 0.73 \\
\hline 25 & $\begin{array}{l}\text { City Hazrat kale shah naya bazar } \\
\text { HP(I) }\end{array}$ & 1.5 & 1.21 & 0.95 & 2.02 & 2.65 & 1.2 & 1.82 & 0.75 \\
\hline 26 & $\begin{array}{l}\text { City Hazrat kale shah naya bazar } \\
\text { HP(I) }\end{array}$ & 1.08 & 1.33 & 1.13 & 2.66 & 2.63 & 0.95 & 1.98 & 0.77 \\
\hline 27 & Atrauli HP(I) & 1.13 & 1.26 & 1.17 & 1.48 & 2.65 & 1.25 & 2 & 0.81 \\
\hline 28 & Chattari HP(P) & 1.01 & 1.34 & 1 & 2.66 & 1.44 & 1.08 & 2.4 & 0.74 \\
\hline 29 & Gardya chauk HP(P) & 1.06 & 1.29 & 1.2 & 3.54 & 1.43 & 1.06 & 2.16 & 0.78 \\
\hline 30 & Janakpur (TW) & 0.96 & 1.29 & 0.95 & 2.06 & 1.62 & 0.99 & 2.3 & 0.8 \\
\hline 31 & Kali nadi, (godha atrauli margpur) & 0.86 & 1.39 & 2.17 & 3.86 & 1.55 & 0.75 & 1.84 & 0.87 \\
\hline 32 & Godha atrauli margpur HP(I) & 0.86 & 1.21 & 1.46 & 3.25 & 2.16 & 0.81 & 2.03 & 0.84 \\
\hline 33 & Memdhi (TW) & 0.82 & 1.25 & 1.21 & 0 & 2.36 & 0.79 & 2.22 & 0.89 \\
\hline 34 & Chattari HP(I) & 0.52 & 1.31 & 1 & 4.49 & 2.25 & 1.16 & 2.57 & 0.85 \\
\hline 35 & Surface water body (Somna canal) & 0.51 & 1.3 & 1.15 & 2.78 & 2.38 & 1.16 & 2.51 & 0.54 \\
\hline 36 & Java HP(P) & 0.38 & 1.95 & 1.3 & 4.3 & 2.37 & 1.24 & 2.4 & 0.54 \\
\hline
\end{tabular}




\begin{tabular}{|c|c|c|c|c|c|c|c|c|c|}
\hline 37 & Cherrat $\mathrm{HP}(\mathrm{P})$ & 0.39 & 1.9 & 1.09 & 5.18 & 2.19 & 0.79 & 2.52 & 0.55 \\
\hline 38 & Ayesha Tarin Public school HP(I) & 0.4 & 1.37 & 1.07 & 6.38 & 2.37 & 0.61 & 2.92 & 0.54 \\
\hline 39 & Jalalpur,Khair road HP(I) & 0.32 & 1.29 & 1.55 & 4.5 & 1.96 & 0.84 & 2.83 & 0.54 \\
\hline 40 & Khair road,Petrol Pump HP(I) & 0.37 & 1.3 & 1.12 & 4.6 & 2.18 & 0.8 & 2.97 & 0.56 \\
\hline 41 & Gonda road, Chauraha HP(I) & 0.65 & 1.41 & 1.09 & 0.57 & 2.03 & 0.95 & 2.84 & 0.59 \\
\hline 42 & Makhdoon nagar HP(I) & 0.5 & 1.58 & 1.26 & 0 & 2.11 & 0.83 & 3.16 & 0.59 \\
\hline 43 & Allana, slaughter house HP(I) & 0.5 & 1.42 & 1.75 & 5.41 & 2.04 & 1.02 & 3.13 & 0.62 \\
\hline 44 & Slaughter house ,HMA Agro HP(P) & 0.45 & 1.85 & 1.23 & 6.14 & 1.31 & 0.73 & 2.93 & 0.63 \\
\hline 45 & Mathura road petrol pump HP(I) & 0.52 & 1.5 & 1.13 & 0.71 & 1.43 & 0.53 & 3.08 & 0.54 \\
\hline 46 & Mathura road HP(I) & 0.46 & 1.4 & 1.06 & 4.19 & 1.36 & 1.11 & 2.88 & 0.6 \\
\hline 47 & Bhujpura chauraha HP(I) & 0.54 & 1.35 & 1.27 & 3.18 & 1.32 & 1.16 & 2.78 & 0.59 \\
\hline 48 & Kasim nagar HP(I) & 0.62 & 1.37 & 1.03 & 3.38 & 1.07 & 1.07 & 3.17 & 0.61 \\
\hline 49 & $\begin{array}{l}\text { Jungle garhi (Bore well } 150 \text { feet } \\
\text { deep) }\end{array}$ & 0.52 & 1.38 & 1.1 & 2.95 & 1.28 & 1.13 & 3.57 & 0.62 \\
\hline 50 & Jungle garhi (Supply water) & 0.64 & 1.85 & 1.3 & 2.77 & 1.53 & 0.96 & 3.45 & 0.63 \\
\hline 51 & Saria mia HP(I) & 0.75 & 1.44 & 1.2 & 0 & 1.43 & 1.22 & 3.14 & 0.63 \\
\hline 52 & Guriya bagh HP(I) & 0.7 & 1.56 & 1.2 & 1.05 & 1.77 & 1.2 & 3.35 & 0.63 \\
\hline 53 & Baradari chauraha (Bore well) & 0.63 & 1.51 & 1.4 & 0 & 1.82 & 1.04 & 3.27 & 0.61 \\
\hline 54 & Baradari chauraha (summer sible) & 0.73 & 1.87 & 1.31 & 1.32 & 1.6 & 1.52 & 3.75 & 0.66 \\
\hline 55 & Kaila nagar HP(I) & 0.83 & 1.5 & 1.44 & 3.54 & 1.57 & 1.64 & 3.24 & 0.62 \\
\hline 56 & Kaila nagar HP(I) & 0.77 & 1.39 & 1.5 & 0 & 1.42 & 0.56 & 3.37 & 0.64 \\
\hline 57 & Medical road dodhpur HP(I) & 0.73 & 1.4 & 1.55 & 5.43 & 1.43 & 0.93 & 3.29 & 0.66 \\
\hline 58 & Jamalpur, near eidgah HP(I) & 0.76 & 1.5 & 1.54 & 5.03 & 5.93 & 0.99 & 3.37 & 0.65 \\
\hline 59 & Near Albarkat jamalpur HP(I) & 0.83 & 1.3 & 1.52 & 4.26 & 2.99 & 0.97 & 3.34 & 0.63 \\
\hline 60 & Dairy farm, Anoopshar road HP(I) & 0.82 & 1.45 & 1.67 & 3.66 & 2.73 & 0.84 & 3.09 & 0.64 \\
\hline 61 & Cherrat,near Heinz HP(P) & 0.94 & 1.43 & 1.52 & 5.86 & 2.65 & 0.5 & 3.23 & 0.6 \\
\hline 62 & Java HP(P) & 0.72 & 1.4 & 1.78 & 2.29 & 1.21 & 1.02 & 3.05 & 0.61 \\
\hline 63 & Kali nadi(Chattari ) & 0.65 & 1.04 & 1.79 & 4.97 & 0.98 & 0.8 & 3.85 & 0.62 \\
\hline 64 & Kali nadi(Chattari) & 0.63 & 1.02 & 1.43 & 0 & 1.26 & 0.79 & 3.38 & 0.58 \\
\hline 65 & Kali nadi(Chattari) & 0.52 & 0.97 & 1.16 & 6.11 & 1.2 & 0.97 & 3.38 & 0.54 \\
\hline 66 & Chattari Bulandshar HP(I) & 0.62 & 1.03 & 1.1 & 7.5 & 1.07 & 0.78 & 3.5 & 0.57 \\
\hline 67 & Chattari Main Market HP(P) & 0.64 & 1.14 & 1.2 & 4.47 & 1.12 & 1.13 & 3.21 & 0.54 \\
\hline 68 & Kamona Gau HP(P) & 0.71 & 1.1 & 1.1 & 5.85 & 1.05 & 0.78 & 2.78 & 0.57 \\
\hline 69 & Pahasu HP(P) & 0.77 & 1.16 & 0.9 & 0.44 & 1.43 & 0.8 & 3.14 & 0.59 \\
\hline 70 & Kali nadi ,(shikarpur road phasu) & 0.85 & 1.27 & 1.1 & 5.29 & 1.61 & 0.93 & 4.33 & 0.68 \\
\hline 71 & Kali nadi ,(shikarpur road phasu) & 0.79 & 1.32 & 1.1 & 3.74 & 0.21 & 1.08 & 4.18 & 0.67 \\
\hline 72 & $8 \mathrm{~km}$ before shikarpur road TW & 1.08 & 1.23 & 1 & 3.11 & 0.08 & 0.98 & 4.25 & 0.71 \\
\hline 73 & Kali nadi( Bulandshar upstream) & 0.84 & 1.28 & 1 & 2.91 & 0.8 & 0.79 & 4.05 & 0.67 \\
\hline 74 & Kali nadi( Bulandshar upstream) & 0.7 & 1.29 & 1.1 & 3.05 & 0.8 & 0.87 & 4.02 & 0.72 \\
\hline 75 & Bulandshar HP(P) & 0.9 & 1.55 & 0.8 & 3.04 & 1.7 & 1.19 & 3.64 & 0.72 \\
\hline 76 & Sarsol HP(I) & 0.76 & 1.52 & 1.2 & 1.3 & 2 & 1.15 & 4.3 & 0.75 \\
\hline 77 & ITI Aligarh HP(I) & 0.92 & 1.44 & 1.5 & 3.08 & 1.86 & 0.84 & 4.25 & 0.71 \\
\hline 78 & Exhibition ground HP(I) & 0.85 & 1.91 & 1.5 & 3.2 & 1.63 & 1.04 & 4.19 & 0.75 \\
\hline 79 & Delhi gate, HP(I) & 0.99 & 1.73 & 1.6 & 1.24 & 1.85 & 1.28 & 3.72 & 0.75 \\
\hline 80 & Upper kote HP(I) & 0.8 & 1.78 & 1.2 & 1.78 & 1.62 & 1.25 & 3.68 & 0.8 \\
\hline 81 & $\begin{array}{l}\text { Madar gate, Achal road chauraha } \\
\text { HP(I) }\end{array}$ & 0.83 & 1.76 & 1.2 & 2.31 & 1.99 & 1 & 3.82 & 0.88 \\
\hline 82 & Saria sultan agra road HP(I) & 0.7 & 1.91 & 1.3 & 0.76 & 1.89 & 1.44 & 3.88 & 0.89 \\
\hline 83 & Khirni road,agra road HP(I) & 0.61 & 1.96 & 1.2 & 1.27 & 2.03 & 1.23 & 4.58 & 0.87 \\
\hline 84 & Sasni gate HP(I) & 0.64 & 1.76 & 1.3 & 0 & 2.16 & 1.48 & 4.69 & 0.9 \\
\hline 85 & Rasalganj HP(I) & 0.92 & 1.85 & 1.3 & 1.33 & 2.37 & 1.04 & 4.39 & 0.92 \\
\hline 86 & Dhanipur mandi Etah road HP(I) & 0.89 & 1.96 & 0.8 & 0.88 & 2.05 & 1.5 & 4.62 & 0.9 \\
\hline 87 & Firdaus nagar HP(I) & 0.84 & 1.85 & 0.7 & 1.28 & 2.18 & 1.2 & 4.87 & 0.9 \\
\hline 88 & Qila road HP(I) & 0.74 & 1.76 & 1.2 & 1.55 & 2.16 & 1.4 & 5.14 & 0.95 \\
\hline
\end{tabular}




\begin{tabular}{|l|l|l|l|l|l|l|l|l|l|}
\hline 89 & $\begin{array}{l}\text { Patwari ka nagla opp riding field } \\
\text { HP(I) }\end{array}$ & 0.6 & 1.84 & 1 & 0 & 2.3 & 1.21 & 5.14 & 0.3 \\
\hline 90 & Patwari ka nagla street no 1 HP(I) & 0.73 & 1.68 & 0.9 & 0 & 2.2 & 1.29 & 5.25 & 0.36 \\
\hline 91 & Shehanshabad HP(I) & 0.68 & 1.8 & 0.92 & 0.86 & 2.07 & 1.1 & 4.86 & 0.41 \\
\hline 92 & Riaz colony HP(P) & 0.56 & 1.95 & 1.15 & 0 & 1.12 & 1.26 & 4.76 & 0.39 \\
\hline 93 & Barola HP(I) & 0.46 & 1.76 & 1.4 & 2.65 & 1.66 & 1.11 & 4.4 & 0.44 \\
\hline 94 & Loco abadi HP(I) & 0.39 & 1.66 & 1.35 & 2.2 & 1.83 & 1.43 & 4.99 & 1.04 \\
\hline 95 & Govind nagar, near bhujpura HP(I) & 0.44 & 2.21 & 1.3 & 1.2 & 1.6 & 1.22 & 5.18 & 1.04 \\
\hline 96 & Shahjamal near karbala (Bore well) & 0.36 & 1.91 & 0.91 & 0.4 & 1.65 & 1.22 & 3 & 0.51 \\
\hline 97 & Shahjamal near karbala HP(I) & 0.29 & 1.87 & 0.96 & 1.8 & 2.7 & 1.44 & 4.51 & 0.49 \\
\hline 98 & Shahjamal opp Eidgah gate HP(I) & 0.45 & 1.78 & 1.83 & 1.8 & 3 & 1.18 & 5.14 & 0.44 \\
\hline 99 & Kali nadi (Cherra)1km from Pilakao & 0.55 & 1.93 & 1.23 & 4.1 & 1.05 & 1.55 & 4.91 & 0.44 \\
\hline 100 & Kali nadi (Cherra)1km from Pilakao & 0.65 & 1.65 & 1.16 & 1.05 & 1.48 & 1.25 & 4.53 & 0.44 \\
\hline & Average & 0.851 & 1.451 & 1.142 & 2.544 & 1.904 & 1.071 & 3.022 & 0.646 \\
& & 4 & 7 & 8 & 1 & 9 & 3 & 2 & 1 \\
\hline
\end{tabular}

\section{References:-}

1. Barzilay, J.I., W.G. Weinberg, and J.W. Eley, (1999): The water we drink water quality and its effect on health: New Brunswick, New Jersey, Rutgers University Press pp. 152.

2. BIS 1993, Indian standard specifications for drinking water, B.S. 13849.

3. Faizanul Mukhtar, M.Yusuf Ansari and Hemida chisti : "A Statistical and mathematical Approach in studying the surface water quality by evaluating the physico-chemical parameters of Hazratbal basin of Dal Lake, Kashmir," J. environmental science and engineering, vol. 56(4), pp 363-374 (2014).

4. Gordou, Wendy (1984): A citizens handbook on ground water protection: New York, natural resources defence council pp. 193.

5. Journal of water resources and protection V 3, pp, 522-530.

6. Mugica, V., Maubert, M, Torres, M. Munoz, J, and Rico, E (2002): Temporal 4 spatial variations of metal content in TSP and PM 10 in Mexico city during 1996-1998.

7. Journal of Aerosol Science, 33, pp, 91-102. Nriagn Jo (1979): Global inventory of natural and anthropogenic emission of trace elements to the atmosphere nature 279: pp. 409-411.

8. Nrigaes J.O. Pacyna J.M. (1988): Quantitative assessment of world wide contamination of trace elements nature 333: pp. 154-139.

9. Raju, N.J., 2006: Iron contamination ground water. A case from tirunala-tirupati, environs, India the researcher, publication, v1 pp. 32-35.

10. Tariq Salam Ansari, I.H. Farooqui and Amiya Akram, (2008): "Chromium removal by soil scape filter", proceeding of Act India Seminar Advance in environmental science and technology, the institution of engineers India, February 15-16, 2008, pp. 59-63 CPCB,(2008).status of groundwater quality in India -part-II, Groundwater quality series: GWQS/2007-2008.

11. SEGH (2001): environmental geo-chemistry and health special issue. In $18^{\text {th }}$ European conference v.23, No. 3. Train, R.E. (1979). Quality criteria for water Washington: DAEPA. Pp. 256.

12. WHO 2004, Guidelines for drinking water quality WHO General. 